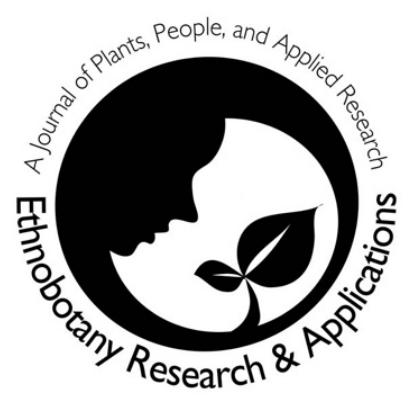

\title{
Potential uses of lycophytes and ferns in Sri Lanka: an ethnopteridological perspective
}

\author{
R.H.G. Ranil and Rainer W. Bussmann
}

\section{Databases and Inventories}

\begin{abstract}
Background: Ethnopteridology is a branch of ethnobotany researching the relationship between pteridophytes and humans. Unlike many seed plants, pteridophytes are generally not extensively used. However, it has long been reported that tropical ferns are used by various indigenous communities. Literature highlighted that to date no comprehensive ethnoperidological survey was performed in Sri Lanka, though it is known that some pteridophytes are used by local communities as home remedies and food sources. Our objective was to present a comprehensive review of the relationships between the pteridophytes and local communities.
\end{abstract}

Methods: We tried to compile a list of potential uses of pteridophytes of Sri Lanka after a comprehensive review of relevant literature and based on gathered information from informal discussions with village communities and indigenous medical practitioners.

Results: Here we identified 37 species with medicinal, food, ornamental, and other uses. Of these 10 species have categorized as threatened under the National Red List-2020. This article documents that pteridophytes have immense potential to be used as food, medicinal and ornamental, and that they still remain neglected.

Conclusions: It is evident that although a considerable number of Sri Lankan pteridophyte species have potential as food, medicinal and ornamental species, they still remain underutilized and neglected crop genetic resources. Further, this study is emphasized that such species and their associated knowledge are at risk and highly vulnerable to changing physical environment, increasing population pressure, and rapid development of socio-economic status of Sri Lanka.

Keywords: Ethnopteridology, Indigenous knowledge, Traditional uses, Folk taxonomy

\section{Correspondence}

\section{R.H.G. Ranil ${ }^{1 *}$ and Rainer W. Bussmann²}

${ }^{1}$ Department of Crop Science, Faculty of Agriculture, University of Peradeniya, Sri Lanka

2Department of Ethnobotany, Institute of Botany, Ilia State University, Tbilisi, Georgia

“Corresponding Author: rrajapaksha@agri.pdn.ac.lk

Ethnobotany Research \& Applications 21:36 (2021)

\section{Background}

All over the world, there has been an increasing interest in the scientific study of man-plant interactions in the natural environment (Davis et al. 2009; Guiney \& Oberhauser 2009; Nisbet \& Zelenski 2013; Srivastava 2007). Today, ethnobotany has become an important and crucial area of research for resource management, and conservation of biodiversity, at genetic, species and ecosystem levels, and socio-economic development (Srivastava 2007). Ethnopteridology is a branch of Ethnobotany that studies the uses of ferns by humans (Keller \& Prance, 2015).

Though there are many investigations of the economic values of edible higher plants, pteridophytes mostly been ignored (Mannan et al. 2008). Although pteridophytes are of minor ecological and economic significance today, they 
dominated the world's vegetation and contributed much to the world's coal reserves (de Winter \& Amoroso 2003). Since remote times human populations in many parts of the world have made use of ferns and lycophytes. The archaeological literature offers much evidence of the close relationship between humans and these plants over many generations (Keller \& Prance 2015). As the first vascular plants, pteridophytes are an ancient lineage, and human beings have been documented to have been using pteridophytes for over 2000 years (Baskaran et al. 2018).

According to Keller \& Prance (2015) fern ethnobotany is nothing new, and that there is lots of data about ferns and local cultures in literature. Keller \& Prance (2015) provided the most comprehensive review on the uses of lycophytes and ferns on a global scale. Ethnobotanical studies of ferns and lycophytes have been carried out in South America (Keller et al. 2011). Though Asia harbors the remarkable diversity of pteridophytes, their uses have not been properly documented, except for some studies in China and India (Srivastava 2007; Mannan et al. 2008; Singh \& Singh 2012; Benniamin 2011; Sinh \& Khare 2011; Yumkham 2017; Singh \& Rajkumar 2017; Singh 2018).

Despites its small land size, Sri Lanka harbors nearly 390 pteridophyte taxa with 42 endemics, but they are still not adequately taxonomically studied in comparison to the neighboring countries (Ranil et al. 2021a). Sri Lanka's pteridophytes are important both at a regional and global scale because of the country's position as a major, western outlier of the Asia-Pacific pteridophyte flora (Ranil et al. 2019). The National Red List-2020 highlighted that out of 350 native taxa, $59 \%$ are in the threatened category (Ranil et al. 2020). Future studies should mainly focus on their biological conservation and sustainable management. Moreover, the exploration of their economic potential is important. Ranil et al. (2021b) highlighted that to date no comprehensive ethnoperidological survey was performed in Sri Lanka, though it is known that some pteridophytes are used by local communities as home remedies and food sources. Our objective was to present a comprehensive review of the relationships between the pteridophytes and local communities.

\section{Materials and Methods}

Information was mainly collected after reviewing historical and recent publications. Information related to medicinal uses was validated in consultations with indigenous medical practitioners, after obtaining their oral prior informed consent. Previously documented information was analyzed, critically evaluated, and updated, integrating information obtain from uses of pteridophytes worldwide. The first author used and critically examined his personal field notes on surveys of specimen collections of Sri Lankan ferns over the period from 2003 to 2020 . Because such a large time was covered, there was no unified methodology, other than participants provided oral prior informed consent.After analyzing all collected data, the information was arranged under their medicinal, food, ornamental, and another minor or uncommon uses and agricultural importance along with their special characteristics relevant to uses. We also compiled all common names used for pteridophytes found in literature and based on interview data. Botanical names were arranged according to the PPGI system. All species were arranged alphabetically in each table under different use categories.

\section{Results and Discussion Ethnopteridological history of Sri Lanka}

Paul Hemann's Ceylon herbarium, dating back to the period of 1672-1679, while he was serving as a chief medical officer for the Dutch East India Company, is considered the first systematic collection of the flora of Sri Lanka, (Cramer 2005; Andel \& Barth 2018; Andel et al. 2018). His specimen collection included few pteridophyte specimens and drawings and is currently deposited at four European herbaria (Andel \& Barth 2018; Ranil et al.2021b). Hemann mentioned the ethnobotanical uses and common names for few fern species collected during his tenure in colonial Ceylon.

Alexander Moon worked from 1821-1843 as the first superintendent of the Royal Botanic Garden, in Peradeniya, Sri Lanka, and gave special attention to collect local names for plants during his botanical work in Sri Lanka. Moons' first acquaintance with Sri Lankan plants was associated with a subsequent relationship with the local people and their innate interest in the plants in their surrounding environment (Cramer 2001). He used such knowledge and experience in his nomenclatural system of native plants of Sri Lanka (A Catalogue of the Indigenous and Exotic Plants Growing in Ceylon, 1824). Moon's list of plants includes 3360 vernacular names (Petch 1922), including of 38 pteridophyte species. Moon's catalog is one the best examples of the use of traditional knowledge of plants for botanical nomenclature. He was the first botanist who documented the local term for ferns as "meewana". Part of his pteridophyte list is given in Figure 1, while Table 1 shows some of the local named used in his list. Trimen (1885) also listed some of the pteridophyte species with their local names in his systematic catalog of the flowering plants and ferns of Ceylon. Apart from mentioning local names, none of them however provided any detailed information on their uses by the local community. 
Ranil et al. (2004) compiled a list of pteridophytes used by village communities during their diversity assessment of lycophytes and ferns in Kanneliya Man and Biosphere Reserve. Moreover, Ranil et al. (2005) conducted a survey on uses of pteridophytes while interviewing village physicians and indigenous community members, and summarized the food, ornamental and medicinal value of pteridophytes with examples. The potential of pteridophytes for the Sri Lankan floriculture industry has discussed by Ranil et al. (2015), while providing a wealth of information on aesthetic values and market values of native pteridophytes.

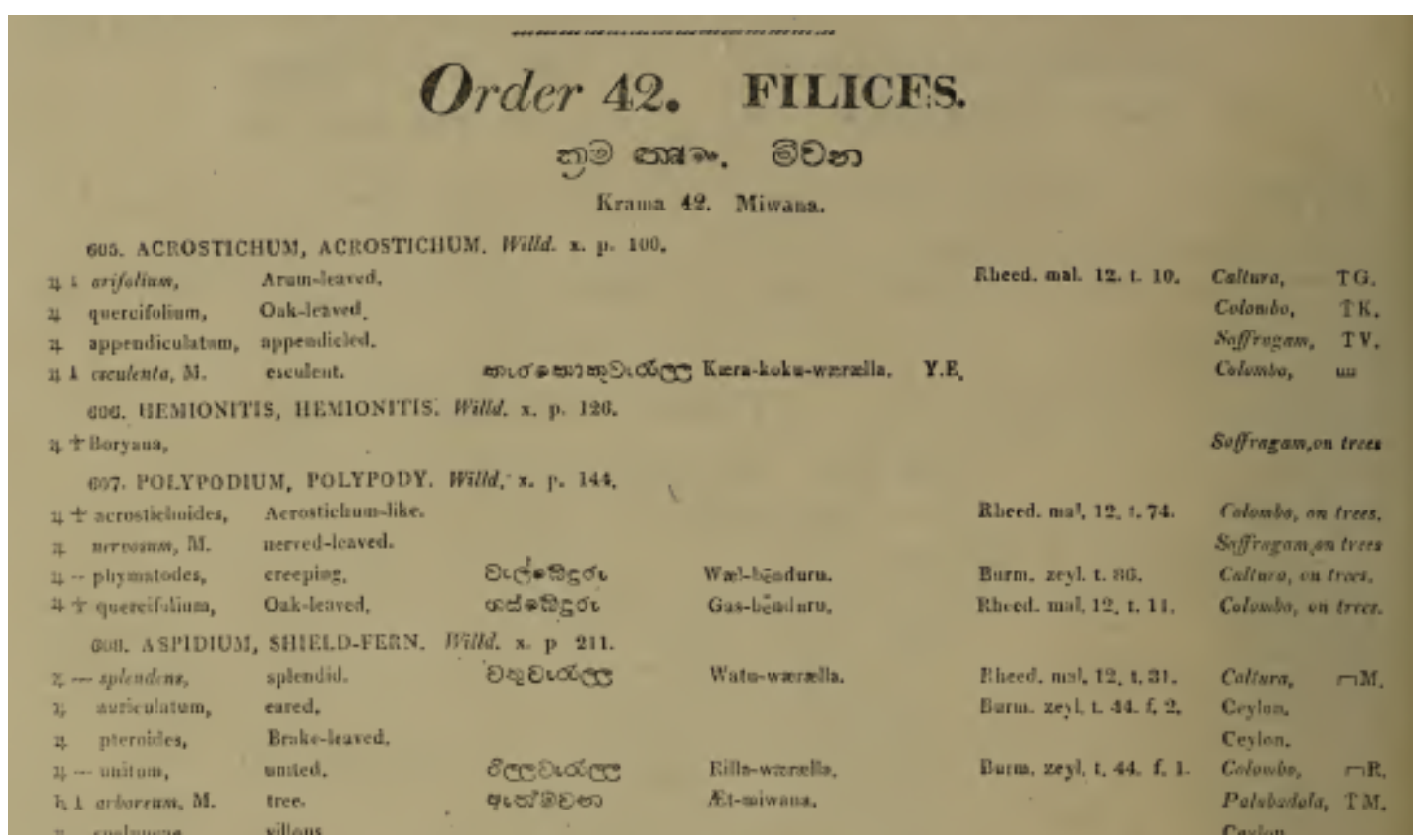

Figure 1. A part of a page of Moons catalog with common names written in native language.

Table 1. A comparison between historically used common names and current names

\begin{tabular}{|c|c|c|c|}
\hline $\begin{array}{l}\text { Botanical name used } \\
\text { by Moon (1884) }\end{array}$ & $\begin{array}{l}\text { Common name used } \\
\text { by Moon (1884) }\end{array}$ & $\begin{array}{l}\text { Name according to PPGI } \\
(2016)\end{array}$ & $\begin{array}{l}\text { Currently used } \\
\text { common name }\end{array}$ \\
\hline Acrostichum esculenta & Kaer-koku-waeraella & Acrostichum aureum L. & Keran-koku \\
\hline Adiantum lunulatum & Kaha-waeralla & Adiantum philippense L. & Not found \\
\hline Aspidium arboreum & Aet-miwana & $?$ & Not found \\
\hline Aspidium splendens & Watu-waeraella & $\begin{array}{l}\text { Nephrolepis biserrata (Sw.) } \\
\text { Schott }\end{array}$ & Rilla \\
\hline Aspidium unitum & Rilla- waeraella & $\begin{array}{l}\text { Cyclosorus interruptus (Willd.) H. } \\
\text { Itô }\end{array}$ & Not found \\
\hline Aspidium viviparum & Ganga-miwana & ${ }^{*}$ Polystichum heterolepis Fée & Not found \\
\hline Asplenium esculentum & Miwana-pala & $\begin{array}{l}\text { Diplazium esculentum (Retz.) } \\
\text { Sw. }\end{array}$ & Miyena-dalu \\
\hline Blechnum orientale & Pattra- waeraella & Blechnum orientale L. & Baru-koku, Pattra-gas \\
\hline Lomaria scandens & Wael-barandara & $\begin{array}{l}\text { Stenochlaena palustris (Burm. f.) } \\
\text { Bedd. }\end{array}$ & Not found \\
\hline Polypodium & Wael-benduru & $\begin{array}{l}\text { Microsorum scolopendria } \\
\text { (Burm. f.) Copel. }\end{array}$ & Not found \\
\hline $\begin{array}{l}\text { Polypodium } \\
\text { quercifolium }\end{array}$ & Gas-benduru & Drynaria quercifolia (L.) J. Sm & $\begin{array}{l}\text { Benduru, Del-path } \\
\text { benduru }\end{array}$ \\
\hline Pteris lanuginosa & An-kaekilla & $\begin{array}{l}\text { Pteridium revolutum (Blume) } \\
\text { Nakai }\end{array}$ & Monara-kekilla \\
\hline Pteris thalictroides & Pilihudu-pala & $\begin{array}{l}\text { Ceratopteris thalictroides (L.) } \\
\text { Brogn. }\end{array}$ & $\begin{array}{l}\text { Gona-un, Pilihudu- } \\
\text { pala }\end{array}$ \\
\hline
\end{tabular}

Note: *There are no records to prove occurrence of Polystichum heterolepis Fée in Sri Lanka. Apparently, it is a misidentification of other common Polystichum species in Sri Lanka. 


\section{Folk nomenclature}

Folk taxonomy deals with the traditional naming and classification of organisms and unlike its scientific counterpart, folk taxonomy is mostly undocumented (Phaka et al. 2019). Folk names of plants are the basis of traditional plant biodiversity knowledge (Khasbagan \& Soyolt 2008). Such folk names assigned to species often carry etymological information such as therapeutic effects, morphological features, mythical connotations, and allegorical values (Nnamani et al. 2019). For example, in Sri Lanka Pyrrosia heterophylla is locally called "kasi-pethi" which translates to "coins." Due to their morphological similarity to coins, the fleshy and rounded leaves are in fact used as coins by local children in their playhouses (Fig. 2G). Ceratopteris thalictroides is locally known as "Gona-an" which means "horns of sambar deer" based on its similar leaf morphology to horns of a deer. Apparently, the local name, "Gini-hota" for tree ferns, (Gini= fire, hota = beak) was derived from its specific use by village communities in the lowland rainforest of Sri Lanka. Once burnt, the upper part of the stem with a coiled frond appears like a burning beak of a bird. The vernacular names used by Sri Lankans across the county are given in Table 2 .

Table 2. Common names used for pteridophytes of Sri Lanka

\begin{tabular}{|c|c|}
\hline Family and botanical names & Common names \\
\hline \multicolumn{2}{|l|}{ Aspleniaceae } \\
\hline Asplenium nidoides Fraser-Jenk. \& Kandel & Kurulu-kedeli-meewana, Gal-palu \\
\hline \multicolumn{2}{|l|}{ Athyriaceae } \\
\hline Diplazium esculentum (Retz.) Sw. & $\begin{array}{l}\text { Miwana-pala, Miyena-dalu, Idal-pala, } \\
\text { Kokum-pala }\end{array}$ \\
\hline \multicolumn{2}{|l|}{ Blechnaceae } \\
\hline Blechnopsis orientalis (L.) C. Presl & Baru-koku, Pattra-gas \\
\hline Stenochlaena palustris (Burm. f.) Bedd. & Wael-barandara \\
\hline \multicolumn{2}{|l|}{ Cyatheaceae } \\
\hline Alsophila walkerae (Hook.) J. Sm. & Gini-hota, Gini-watara, Pattra-gas \\
\hline Gymnosphaera gigantea (Wall. ex Hook.) S.Y. Dong & do \\
\hline Sphaeropteris crinita (Hook.) R.M. Tryon & do \\
\hline \multicolumn{2}{|l|}{ Dennstaedtiaceae } \\
\hline Pteridium revolutum (Blume) Naka & Monara-kekilla, An-kekilla \\
\hline \multicolumn{2}{|l|}{ Gleicheniaceae } \\
\hline Dicranopteris linearis (Burm. f.) Underw. & Kekilla \\
\hline Dicranopteris taiwanensis Ching \& P.S. Chiu & Kekilla \\
\hline \multicolumn{2}{|l|}{ Lycopodiaceae } \\
\hline Palhinhaea cernua (L.) Franco \& Vasc. & Badal-hanassa \\
\hline Phlegmariurus phlegmaria (L.) Holub & Maha-hedaya \\
\hline \multicolumn{2}{|l|}{ Phlegmariurus phyllanthus (Hook. \& Arn.) R.D. Dixit } \\
\hline Phlegmariurus squarrosus (G. Forst.) A. Löve \& D. Löve & Kuda-hedaya \\
\hline \multicolumn{2}{|l|}{ Lygodiaceae } \\
\hline Lygodium microphyllum (Cav.) R. Br. & Pamba-wel \\
\hline Lygodium flexuosum (L.) Sw. & Pamba-wel \\
\hline Lygodium circinnatum (Burm.f .) Sw. & Maha-pamba \\
\hline \multicolumn{2}{|l|}{ Marattiaceae } \\
\hline Angiopteris crassipes Wall. ex C. Presl. & Wal-meda \\
\hline Angiopteris helferiana C. Presl. & Wal-meda \\
\hline \multicolumn{2}{|l|}{ Marsileaceae } \\
\hline $\begin{array}{l}\text { Marsilea coromandelina Willd. } \\
\text { Marsilea minuta L. }\end{array}$ & Hathara-petiya, Pethi-pala \\
\hline \multicolumn{2}{|l|}{ Nephrolepidaceae } \\
\hline Nephrolepis biserrata (Sw.) Schott & Watu-werella, Rilla \\
\hline Nephrolepis falciformis J. Sm. & Rilla \\
\hline Nephrolepis brownii (Desv.) Hovenkamp \& Miyam. & Rilla \\
\hline \multicolumn{2}{|l|}{ Ophioglossaceae } \\
\hline Helminthostachys zeylanica (L.) Hook. & Thani-wel \\
\hline Ophioderma pendula (L.) C. Presl. & Pati-dhatu \\
\hline Ophioglossum reticulatum $\mathrm{L}$. & Ek-pethi-pium \\
\hline
\end{tabular}

Polypodiaceae

Drynaria quercifolia (L.) J.Sm.

Benduru, Del-path benduru 
Pyrrosia heterophylla (L.) M.G. Price

Microsorum scolopendria

(Burm.f.) Copel.

Pteridaceae

Acrostichum aureum L.

Adiantum capillus-veneris $\mathrm{L}$.

Adiantum caudatum $\mathrm{L}$.

Adiantum philippense $\mathrm{L}$.

Ceratopteris thalictroides (L.) Brogn.

Parahemionitis cordata (Roxb. ex Hook. et Grev.) Fraser-Jenk.

Thelypteridaceae

Cyclosorus interruptus (Willd.) H. Itô

\section{Medicinal uses}

Studies of uses of ferns in ethnomedicine are abundant on all inhabited continents, e.g. Americas and Asia (Keller and Prance, 2015). Recent and updated information on the medicinal uses of ferns in Europe and Africa is however, astonishingly, not readily available. Pteridophytes can be considered an important group of plants in Asian folklore medicine. Mannan et al. (2008) have explained their uses in the Homoeopathic, Ayurvedic, Tribal, and Unani medicines. Among Asian countries, Indian pteridophytes have been extensively studied for their ethnomedicinal uses (Singh \& Rajkumar 2017).

Communities in Sri Lanka have developed their own medical system over a period of 3000 years, based on a series of prescriptions handed down from generation to generation (Samaranayake \& Pushpakumara 2016), and plants and their products have been systematically used for treating illnesses
Kasi-pethi, Panam-pethi, Salli-pethi

Wael-benduru

Keran-koku

Wal-venna

Thuda-wediya

Kaha-waeralla

Gona-an, Pilihudu-pala

Kalu-goltukola

Table 3. Medicinally important species and their significance

\begin{tabular}{ll}
\hline Species & Medicinal properties/ uses \\
\hline Adiantum caudatum L. & $\begin{array}{l}\text { The leaves are used in diabetes and as a cure for coughs and } \\
\text { fevers. Externally, they are applied on diseases of the skin. }\end{array}$ \\
\hline Adiantum philippense L. & $\begin{array}{l}\text { The leaves are used internally for febrile ailments and applied } \\
\text { externally on erysipelatous inflammations. A plaster made from } \\
\text { the rhizome is applied on chronic tumors. }\end{array}$ \\
\hline Helminthostachys zeylanica (L.) Hook. & $\begin{array}{l}\text { The rhizomes are used in the treatment of syphilis, dysentery, } \\
\text { catarrh, whooping, cough and phthisis. }\end{array}$ \\
\hline Ophioglossum reticulatum L. & $\begin{array}{l}\text { The plant is used for treating wasting diseases, arresting sexual } \\
\text { weakness and painful micturition. It is also employed for the } \\
\text { treatment of insanity. }\end{array}$ \\
\hline Palhinhaea cernua (L.) Franco \& Vasc. & $\begin{array}{l}\text { A decoction of the plant is given for coughs and as a diuretic. It } \\
\text { is effective for dysentery, gout and rheumatism. An embrocation } \\
\text { of the ashes of the plant with vinegar is recommended for } \\
\text { eruption. }\end{array}$ \\
\hline $\begin{array}{l}\text { Psed in the preparation of medicinal oil for the treatment of } \\
\text { snakebite. }\end{array}$ \\
\hline $\begin{array}{l}\text { Phlegmariurus squarrosus (G. Forst.) } \\
\text { Aöve \& D. Löve }\end{array}$ & $\begin{array}{l}\text { Used in the preparation of medicinal oil for the treatment of } \\
\text { snakebite (Jayaweera, 2006). }\end{array}$ \\
\hline Pyrrosia heterophylla (L.) M.G. Price & $\begin{array}{l}\text { The leaves are used as a styptic to arrest capillary hemorrhages } \\
\text { and on eczema. }\end{array}$ \\
\hline Selaginella wightii Hieron. & $\begin{array}{l}\text { This plant is used in the preparation of medicinal oils for treatment } \\
\text { of paralysis. }\end{array}$ \\
\hline
\end{tabular}

for at least a thousand years (Napagoda et al. 2018). Among the native flora of Sri Lanka, more than 1400 plants are used in indigenous medicine (Sugathadasa et al. 2008; Wijesundara 2004). However, these authors hardly included any pteridophytes while estimating the number of plants with medicinal properties, perhaps due to inadequate literature and lack of current uses. None of the European collectors in Sri Lanka documented in detail medicinal ferns in their botanical, ecological, and environmental surveys, and they also failed in general to provide detailed information on their ethnomedicinal uses and medicinal properties. Jayaweera (1984) is the only botanist who complied detailed information on the medicinal properties and uses of a few pteridophyte species, but this comprehensive work is limited to eight pteridophyte species of Sri Lanka (Table 3). 
Apart from the above species, according to community members interviewed around the wet zone forests in Sri Lanka, Acrostichum aureum, Actiniopteris radiata, Blechnopsis orientalis, Diplazium esculentum, Drynaria quercifolia, Lygodium microphyllum, Ophioderma pendula and Parahemionitis cordata are used in the indigenous medicinal system.

\section{Food value}

With very few exceptions, ferns have not been widely used as a source of food (Mannan et al. 2008). Although ferns have been used in traditional cuisines for a long time, information on their pattern of usage, nutritional properties, and recipes is lacking. Lie et al. (2012) reported that the history of eating ferns in China may go back as far as $\mathbf{3 0 0 0}$ years, and edible ferns are some of the most commonly collected wild food plants around the world, with stems, rhizomes, leaves, young fronds, and shoots, and sometimes the whole plants used for food (Lie et al. 2012).

Acrostichum aureum, Blechnopsis orientalis (Fig. 3A) and Diplazium esculentum are the only known edible fern species in Sri Lanka. Except for $D$. esculentum, the other two species are locally common. In an informal discussion with community members in the buffer zone of the Kanneliya Man and Biosphere Reserve, they mentioned that immature fronds of Neprolephis spp. and Dicranopteris linearis were used as food, both fried and in curry, by their ancestors. Yumkham et al. (2006) also mentioned the food value of Nephrolepis and Dicranopteris species in North East India.

\section{As ornamental plants}

The Sri Lankan floriculture industry is dominated by exotic species, particularly foliage plants, even though the country is home to many attractive indigenous species. Only a few genera of pteridophytes (e.g. Adiantum, Nephrolepis, and Rumohra) are occasionally exported as ornamental foliage plants (Export Development Board, 2011). All these are however exotic species, and none of the Sri Lankan species are popular in the local and international ornamental industry. A list of potential ornamental pteridophyte species has been published by Ranil et al. (2005) while discussing their potential for the Sri Lankan floriculture industry. Table 4 shows Sri Lankan species occasionally used in landscaping. Because most of the attractive and potential species are legally protected by the Fauna and Flora Protection Ordinance, they cannot be cultivated or commercialize without getting proper approval from authorizing agencies. For example, although tree ferns are ideally matched with landscaping models (Fig. 3D \& 3E) all species are protected by a number of acts and ordinances.

Table 4. Species used in landscaping.

\begin{tabular}{ll}
\hline Species & Application \\
\hline Acrostichum aureum L. & Cultivate in and around ponds and indoor waterfalls. \\
\hline Alsophila walkerae (Hook.) J. Sm. & An endemic species used in landscaping. \\
\hline Angiopteris crassipes Wall. ex C. Presl. & Cultivate around ponds. \\
\hline Angiopteris helferiana C.Presl. & Cultivate around ponds. \\
\hline Asplenium nidoides Fraser-Jenk. \& Kandel & Commonly used epiphytic fern. \\
\hline Blechnum occidentale L. & Cultivate around ponds. \\
\hline Doodia caudata (Cav.) R.Br. & Used as bed plants only in high altitude areas. \\
\hline Doodia dives Kunze & Used as bed plants only in high altitude areas. \\
\hline Doodia squarrosa Colenso. & Used as bed plants only in high altitude areas. \\
\hline Doodia media R. Br. & Used as bed plants only in high altitude areas. \\
\hline Drynaria quercifolia (L.) J.Sm. & Commonly used epiphytic fern. \\
\hline Nephrolepis biserrata (Sw.) Schott & A common bed plant. \\
\hline Nephrolepis cordifolia (L.) C. Presl & A common bed plant. \\
\hline Nephrolepis falciformis J. Sm. & A common bed plant. \\
\hline Nephrolepis brownii (Desv.) Hovenkamp \& Miyam. & A common bed plant. \\
\hline Phlegmariurus phyllanthus (Hook. \& Arn.) R.D. Dixit & A rare epiphytic fern. \\
\hline Phlegmariurus squarrosus (G. Forst.) A. Löve \& D. Löve & A rare epiphytic fern. \\
\hline Pityrogramma dealbata (C. Presl) R.M. Tryon & A rare epiphytic fern. \\
\hline Pyrrosia heterophylla (L.) M.G. Price & A common epiphytic fern. \\
\hline Pyrrosia gardneri (Mett.) Sledge & A rarely used endemic epiphytic fern species. \\
\hline Phlegmariurus phlegmaria (L.) Holub & A rare epiphytic fern. \\
\hline Selaginella cochleata (Hook. \& Grev.) Spring & A rarely used bed plant. \\
\hline Sphaeropteris crinita (Hook.) R.M. Tryon & A tree fern species used in high altitude areas. \\
\hline
\end{tabular}



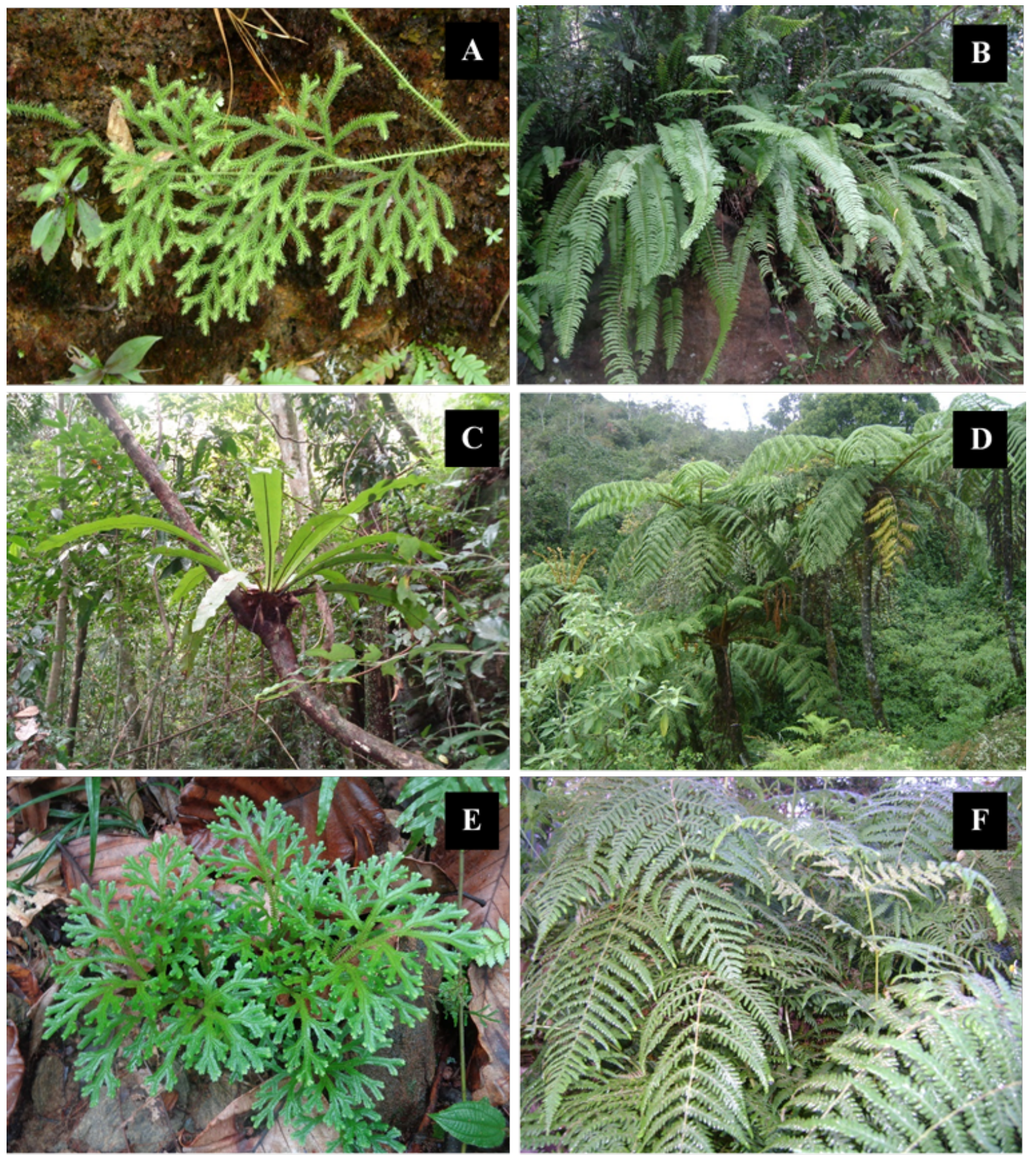

Figure 2. Species used by local community. A. Palhinhaea cernua; B. Nephrolepis falciformis; C. Asplenium nidoides; D. Sphaeropteris crinita; E. Selaginella cochleata; F. Pteridium revolutum.

\section{Agricultural importance}

Sri Lanka is predominantly an agricultural country and is home to highly diverse agricultural ecosystems and important crop genetic resources. Until the introduction of the technology package of the green revolution in the 1960s, traditional knowledge helped our ancestors to keep the country agriculturally sustainable (Ranil et al. 2021b). Local farmers long maintained a sustainable agricultural production system in the country. With the expansion of modern agricultural knowledge and technological practices, many of such indigenous techniques have become underutilized and neglected. For example,
Azolla pinnata R.Br. subsp. asiatica R.M.K. Saunders \& K. Fowler was already used as nitrogen source for paddy cultivation in the past (Kulasooriya 1984) which significantly contributed to reduce the amount of synthetic nitrogen fertilizer needed for paddy cultivation in Sri Lanka. Although Salvinia molesta D. Mitch. is alien invasive species (Wijesundara 2010), traditional farmers now have replaced Azolla with Salvinia to make organic fertilizer in their farmlands.

The plantation crop sector, particularly tea (Camellia sinensis (L.) Kuntze), is a key contributor to the Sri 
Lankan economy in terms of foreign exchange earnings, employment, and food supply (Gunathilaka et al. 2017). In tea cultivation it is essential to provide temporary shade for nursery plants until they are of transplanting age. In small holding tea plant nurseries, farmers are commonly using Dicranopteris linearis and Dicranopteris taiwanensis to provide temporary shade for tea plants, and Pteridium revolutum is also used sometimes for the above purpose.

There is also a high demand for both wild and cultivated orchids in the floriculture industry in Sri Lanka. Small scale orchid growers use logs or pieces of the stem of tree ferns, particularly Alsophila walkerae and Sphaeropteris crinita as growth medium for orchids, although both species are protected under the fauna and flora protection ordinance of Sri Lanka.

Ferns are not always beneficial organisms, and although fern invasions have not gained massive publicity their effects on the environment cannot be overlooked (Akomolafe \& Rahmad 2018). Although more than 157 species in the world have been registered as alien weeds, of which $39 \%$ behave as invasive species (Jones et al. 2019), and a variety are toxic to animals and humans (Siman et al. 2000). Especially in the dry and intermediate zones of Sri Lanka, the farming community is struggling with problems created due to invasion of water bodies by Salvinia molesta, a fast-spreading invasive alien species in Sri Lanka (Wijesundara 2010). Though several attempts were made to control it over the last few decades, $S$. molesta still remains one of the most troublesome aquatic weeds. In tea plantations, Plebhodium aurium is naturalized and usually found on tea bushes as a weed. Adiantum hispidulum Sw. and Christella dentata (Forssk.) Brownsey \& Jermy are other common weeds in upcountry tea plantation.

\section{Uncommon uses}

Apart from their main uses (food, medicine and ornamental) some pteridophyte species are used by the local communities to fulfill some other needs. The stems of Alsophila walkerae are often used to provide support for the climbing of betel vine (Piper betle L.). The stems are also burnt as light source (personal communication with elders in the buffer zone of Kanneliya Forest Reserve.) and the species is also used as firewood and for making fences, instead of wooden poles (Fig. 3F).

Palhinhaea cernua is a locally common species usually growing on roadsides and disturbed forest areas. It use as a bedding material and also used in floral decorations (Ranil et al. 2014). We also observed that scaly leaves of Drynaria quercifolia being used in dry floral decorations. Children use the dry fronds of $D$. quercifilia to make kites. Both Lygodium flexuosum and Lygodium microphyllum find use as rope, when making bundles of leafy vegetables and firewood, and also are used in floral decorations (Fig. 3C). During the constructions of dams for small scale irrigation channels, thick layers of $D$. linearis are used to block the water flow temporary. In gem mines, $D$. linearis is used as filler to block the leaching of water into the mine.

\section{Conclusions}

Here we compiled all available ethnopteridological information of Sri Lankan pteridophytes. It is evident that although a considerable number of Sri Lankan pteridophyte species have potential as food, medicinal and ornamental species, they still remain underutilized and neglected crop genetic resources. All species and their associated knowledge are at risk, and highly vulnerable due to an ever faster changing physical environment, increasing population pressure, and rapid socio-economic development. Collection and documentation of such information are highly needed, because most of the information is still in the hand of the local community without any written documentation. Collection, conservation, and utilization of ethnopteridological knowledge might be effectively used to improve the country's development and conservation.

\section{Declarations}

List of abbreviations: Not applicable.

Ethics approval and consent to participate: Before conducting interviews, prior informed permission was obtained from all stalk holders. No further ethics approval was required.

Consent for publication: This paper does not include any individual person's data and further permission for publication is not required.

Availability of data and materials: The data was not deposited in public repositories.

Conflict of interests : The authors declare that they have no competing interests.

Funding: This study did not receive any specific grant from funding organizations.

Authors' contribution: The first author collected, analyzed, and interpreted the information. The second author improved and edited the first draft. Both authors read, reviewed, and approved the final version of the manuscript.

\section{Acknowledgments}

Authors are indebted to the key informants who represented the indigenous communities and indigenous medical practitioners for providing information on the uses of pteridophytes. Dr. Tharanga Wijewickrama is also acknowledged for providing a picture (Fig. 3A). 

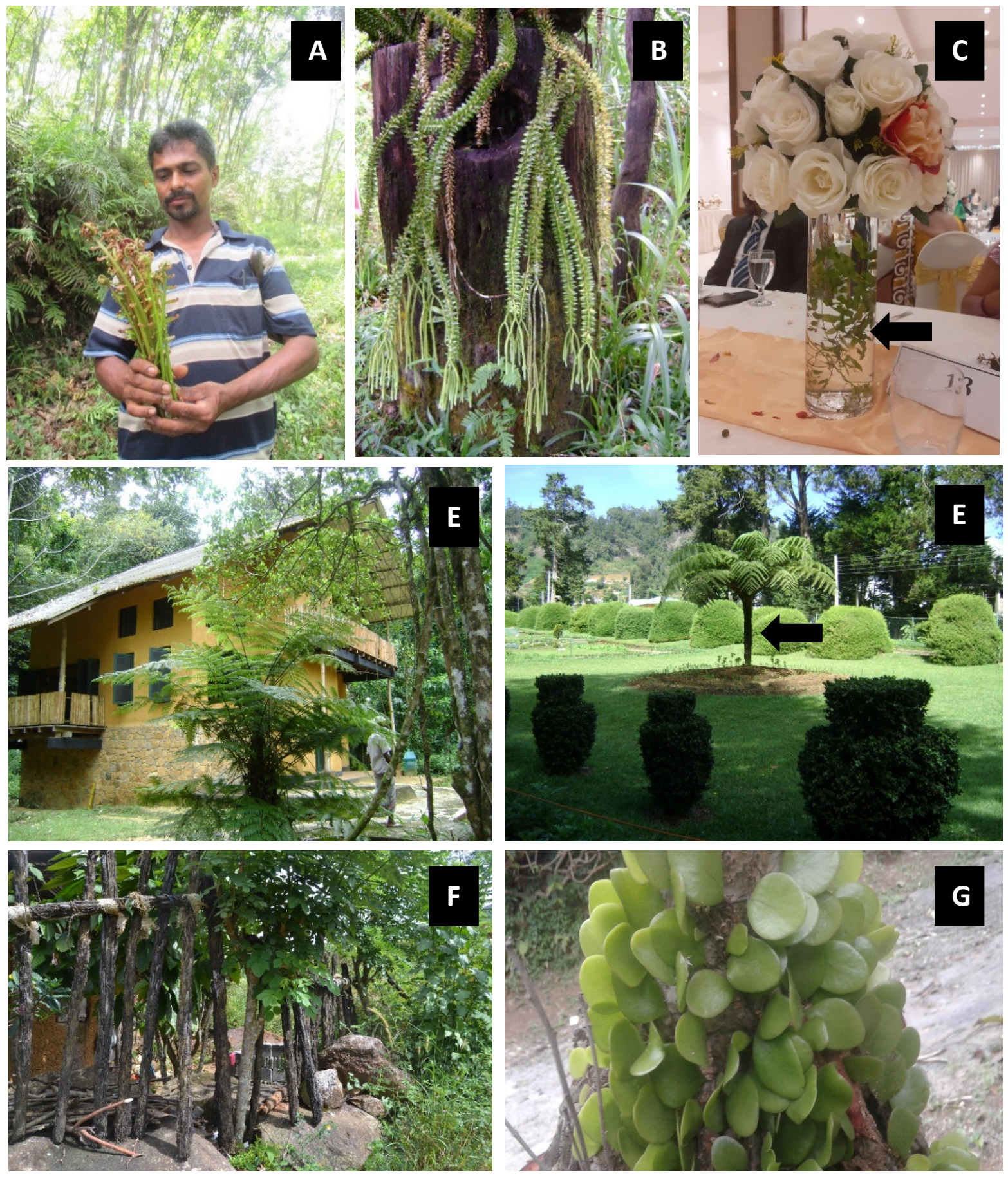

Figure 3. Some uses of pteridophytes in Sri Lanka. A. just after harvesting of immature frond of Blechnum orientale for cooking; B. luxury gown Phlegmariurus phyllanthus in a homegarden; C. use of Lygodium flexuosum in a decoration; D. an endemic Alsophila walkerae used in landscaping; E. Sphaeropteris crinita used in landscaping; F. stems of Alsophila walkerae used to make fences around rural houses; G. fleshy and rounded leaves of Pyrrosia heterophylla.

\section{Literature cited}

Akomolafe GF, Rahmad ZB. 2018. A review on global ferns invasions: mechanisms, management and control. Journal of Research in Forestry, Wildlife and Environment 10(3): 2-54.

Baskaran XR, Vigila AVG, Zhang SZ, Feng SX, Liao WB. 2018. A review of the use of pteridophytes for treating human ailments. Journal of Zhejiang University-Science B 19(2):85-119.

Benniamin A. 2011. Medicinal ferns of North Eastern India with special reference to Arunachal Pradesh. Indian Journal of Traditional Knowledge 10(3): 516522. 
Cramer LH. 2005. The revisionary work on the flora of Sri Lanka. Ceylon Journal of Science. (Biological Science) 34: 1-5.

Davis JL, Green JD, Reed A. 2009. Interdependence with the environment: commitment, interconnectedness, and environmental behavior. Journal of Environmental Psychology 29:173-80. doi:10.1016/j.jenvp.2008.11.001.

Guiney MS, Oberhauser KS. 2009. Conservation volunteer's connection to nature. Ecoposychology 1(4):187-97. doi:10.1089/eco.2009.0030.

Gunathilaka RD, Smart JC, Fleming CM. 2017. The impact of changing climate on perennial crops: the case of tea production in Sri Lanka. Climatic Change140 (3-4):577-592.

Jones EJ, Kraaij T, Fritz H, Moodley D. 2019. A global assessment of terrestrial alien ferns (Polypodiophyta): species' traits as drivers of naturalisation and invasion. Biological Invasions 21(3):861-873.

Keller HA, Prance GT. 2015. The ethnobotany of ferns and Lycophytes. Fern Gazette 20:1-13.

Keller HA, Torres EIM, Prance GT. 2011. Ethnopteridology of the Guaranís of Misiones Province, Argentina. American Fern Journal 101(3):193-204.

Khasbagan S. 2008. Indigenous knowledge for plant species diversity: a case study of wild plants' folk names used by the Mongolians in Ejina desert area, Inner Mongolia, PR China. Journal of Ethnobiology and Ethnomedicine 4, p.2

Kulasooriya SA, Hirimburegama WK, Abeysekera SW. 1984. Azolla as a biofertilizer for rice in Sri Lanka. In Practical Application of Azolla for Rice Production, Springer, Dordrecht. Pp. 188-201.

Liu Y, Wujisguleng W, Long C. 2012. Food uses of ferns in China: a review. Acta Societatis Botanicorum Poloniae, 81(4):263-270.

Mannan MM, Maridass M, Victor, B. 2008. A review on the potential uses of ferns. Ethnobotanical leaflets 12:281-285

Napagoda MT, Sundarapperuma T, Fonseka D, Amarasiri S, Gunaratna P. 2018. An Ethnobotanical Study of the Medicinal Plants Used as AntiInflammatory Remedies in Gampaha District, Western Province, Sri Lanka. Hindawi Scientifica. doi.org/10.1155/2018/9395052.

Nisbet EK, Zelenski JM. 2013. The NR-6: a new brief measure of nature-relatedness. Frontiers in psychology 4:813. doi:10.3389/fpsyg.2013.00813.

Nnamani CV, Atkinson CJ, Nwite JE. 2019. Etymology of Folk Nomenclatures for Sphenostysis stenocarpa (Hoechst ex A. Rich) Harms.

Phaka FM, Netherlands EC, Kruger DJ, Du Preez LH. 2019. Folk taxonomy and indigenous names for frogs in Zululand, South Africa. Journal of ethnobiology and ethnomedicine 15(1):1-8.

Ranil RHG, Pushpakumara DKNG, Wijesundera DSA, Dhanasekara DMUB, Gunawardena HG. 2004. Biodiversity of Pteridophyta in Kanneliya Man and Biosphere Reserve. The Sri Lanka Forester 27: 1-10.

Ranil RHG, Pushpakumara DKNG, Wijesundara DSA, Dhanasekara DMUB. 2005. Uses of Pteridophyte flora in Sri Lanka. $10^{\text {th }}$ Annual Forestry and Environment Symposium, Department of Forestry and Environmental Science, University of Sri Jayewardenepura, Sri Lanka: p.28.

Ranil RHG, Beneragama CK, Pushpakumara DKNG, Wijesundara DSA. 2015. Ornamental pteridophytes: an underexploited opportunity for the Sri Lankan floriculture industry. Journal of National Science Foundation Sri Lanka 201543 (4):293-301. doi: hdoi.org/10.4038/jnsfsr. v43i4.7964.

Ranil RHG, Parris BS, Sundue MA, Chamara RMSR, Pushpakumara DKNG. 2019. The grammitid ferns of Sri Lanka: A situational analysis of the most threatened fern group in Sri Lanka. Proceeding of the $11^{\text {th }}$ Flora Malesiana Symposium, Universiti Brunei Darussalam, Brunei. Pp. 102-104.

Ranil RHG, Gunawardena, NPT, Muthukuda Arachchi DKT, Pushpakumara, DKNG, Wijesundara DSA. 2020. In: The National Red List 2020 Conservation Status of the Flora of Sri Lanka. Sri Lanka: Biodiversity Secretariat of the Ministry of Environment and the National Herbarium, Department of the National Botanic Gardens, Peradeniya 170-188.

Ranil RHG, Fraser-Jenkins CR, Ebihara A, ChengWei Chen, Parris BS, and Hovenkamp P, Sundue M, Pushpakumara DKNG, Wijesundara DSA. 2021a. The updated checklist of pteridophyte flora of Sri Lanka (In press.).

Ranil RHG, Chamara RMSR, Pushpakumara, DKNG, Bussmann RW. 2021b. Exploration, Conservation, and Utilization of Ethnobotanical Knowledge: Sri Lankan Perspective. In Ethnobiology of Mountain Communities in Asia. Abbasi AM, Bussmann RW. Springer International Publishing Pp. 409-332.

https://doi.org/10.1007/978-3-030-55494-1.

Samaranayake GVP, Pushpakumara AAJ. 2016. A literary review on traditional medical systems for cancer in Sri Lanka. In National Research Symposium, Department of Ayurveda Basic Principles, Gampaha Wickramarachchi Ayurveda Institute, University of Kelaniya, Sri Lanka.

Siman ES, Povey AC, Waeds TH, Margison GP, Sheffield E. 2000. Fern spore extracts can damage DNA. British Journal of Cancer 83:69-73.

Singh AP, Khare PB. 2011. Status of ethnopteridology in India. In Applied Botany Abstracts, 
CSIR-National Botanical Research Institute 31(4):332-361.

Singh AV. 2018. Ethnobotany of ferns of Lakhimpur, Assam, India. International Research Journal of Biological Science 7(7):27-34.

Singh S, Rajkumar S.D. 2017. Biodiversity and Indigenous Use of Medicinal Ferns in Chandraprabha Wildlife Sanctuary, Chandauli, Uttar Pradesh", International Journal of Research Studies in Biosciences (IJRSB) 5 (11):19-25. http://dx.doi.org/10.20431/2349-0365.0511004.

Singh S, Singh R. 2012. Ethnomedicinal use of Pteridophytes in reproductive health of tribal women of Pachmarhi Biosphere Reserve, Madhya Pradesh, India. International Journal of Pharmaceutical Sciences and Research 3(12):4780-4790.

Singh SK, Rajkumar SD. 2017. Biodiversity and indigenous use of medicinal ferns in Chandraprabha wildlife sanctuary, Chandauli, Uttar Pradesh. International Journal of Research Studies in Biosciences 5:19-25.

Srivastava K. 2007. Ethnobotanical studies of some important ferns. Ethnobotanical leaflets 2007(1):164172.

Sugathadasa KSS, Jeevandara PM, Devanarayana A, Pushpakumara DKNG. 2008. A Checklist of Medicinal Plants of Sri Lanka. Bandaranike Memoriyal Ayurvedhic Research Institute, Department of Ayurveda, Navinna, Maharagama, Sri Lanka.

Wijesundara S. 2010. Invasive alien plants in Sri Lanka. In: Invasive Alien Species in Sri Lanka Strengthening Capacity to Control Their Introduction and Spread (Eds: Marambe B, Silva P, Wijesundara S, Atapattu N), Biodiversity Secretariat of the Ministry of Environment, Sri Lanka. Pp 27-38.

Wijesundera DSA. (2004) Inventory, documentation and medicinal plant research in Sri Lanka. Medicinal Plants Research in Asia 1:184-95.

Yanez A, Gutierrez DG, Ponce MM. 2020. Weedy ferns (Polypodiopsida) in Argentina: diversity, distribution and impact on human activities and ecosystems. Anais da Academia Brasileira de Ciências 92(1). DOI:10.1590/00013765202020180983

Yumkham SD, Chakpram L, Salam S, Bhattacharya MK, Singh PK. 2017. Edible ferns and fern-allies of North East India: a study on potential wild vegetables. Genetic resources and crop evolution 64(3):467-477. 